\title{
A CASE REPORT OF KLIPPEL- FEIL SYNDROME WITH SPRENGEL'S DEFORMITY
}

Ritu Mital1, Priyanka Gupta², Ajeet Kumar Yadav³

\section{HOW TO CITE THIS ARTICLE:}

Ritu Mital, Priyanka Gupta, Ajeet Kumar Yadav. "A Case Report of Klippel-Feil Syndrome with Sprengel's Deformity". Journal of Evolution of Medical and Dental Sciences 2015; Vol. 4, Issue 16, February 23;

Page: 2850-2854, DOI: $10.14260 /$ jemds/2015/411

ABSTRACT: Klippel-Feil syndrome is a rare disease, characterized by the congenital fusion of any 2 of the 7 cervical vertebrae. ${ }^{1}$ The actual prevalence of Klippel-Feil syndrome is unknown due to the fact that there was no study done to determine its true prevalence. ${ }^{2}$ Although the actual occurrence for the Klippel- Feil syndrome is unknown, it is estimated to occur in 1 in 40, 000 to 42,000 newborns worldwide. In addition, females seem to be affected slightly more often than males. ${ }^{3} \mathrm{We}$ report here a case of Klippel- Feil syndrome who presented to us with neck stiffness and underdeveloped shoulder blades.

KEYWORDS: Scoliosis, block vertebra.

INTRODUCTION: Klippel-Feil syndrome is characterized by congenital fusion ("block vertebra") of a variable number of cervical vertebrae, which may result in atlantoaxial instability. ${ }^{4}$ It is primarily a bone disorder which is present since birth. Three major clinical features of this syndrome are: a short neck, a limited range of neck mobility and a low hairline at the back of the head. Most affected people have one or two of these characteristic features. Less than half of all individuals with Klippel-Feil syndrome have all three classic features of this condition. ${ }^{3}$

Other associated anomalies in these patients can be deafness, genital and urinary abnormalities, and cardiovascular abnormalities.

Congenital elevation of the scapula or 'Sprengel's shoulder' is an anomaly of the shoulder blade that is associated with abnormal descent, and altered position and anatomy of the scapula. The deformity is usually associated with muscle hypoplasia or atrophy, and a combination of these factors results in disfigurement and functional limitation of the shoulder5. Patients with Klippel- Feil syndrome should undergo evaluation for associated abnormalities like fused ribs, absent ribs, congenital scoliosis, and Sprengel's deformity.

CASE REPORT: A 14 years old girl presented to our setting with short stature and restriction of neck movements in all directions. Her medical history revealed that she had not attained menarche. Physical examination revealed flat facies, short neck, low hair line, restricted neck movement, decreased opening of mouth and absent epicanthal folds. Her carrying angle was increased, scoliosis was present, nipples were widely spaced and there was broad shield chest. Height for age was less than $3^{\text {rd }}$ standard deviation. TANNER Score was A1P1B2. Ultrasound abdomen showed presence of ovaries which ruled out Turner's syndrome. Neurological examination was normal. Muscle strength was normal with no muscle atrophy. Radiography of the cervical spine (Lateral view) showed fusion of $5^{\text {th }}$ and $6^{\text {th }}$ cervical vertebra (Block vertebrae), elevated right scapula, crowding of ribs with hemi upper dorsal vertebrae. Klippel-Feil syndrome was diagnosed on above mentioned clinical and radiological findings. 


\section{CASE REPORT}

DISCUSSION: Klippel-Feil syndrome is a congenital fusion of the cervical vertebra that may involve two segments, a congenital block vertebra, or entire cervical spine ${ }^{6}$. It is primarily a bone disorder which can also affect other systems such as cardiorespiratory, genitourinary and auditory system. Less than half of the patients present with the classical triad of restriction of neck movements, low hair line and short neck. Clinically, the most consistent finding is restriction of neck movements. ${ }^{7}$

\begin{tabular}{|c|c|}
\hline Abnormalities associated with Klippel-Feil Syndrome \\
\hline Common abnormalities & $\mathbf{\%}$ \\
\hline Scoliosis & 60 \\
\hline Renal abnormalities & 35 \\
\hline Sprengel deformity & 30 \\
\hline Deafness & 30 \\
\hline Synkinesis & 20 \\
\hline Congenital heart disease & 14 \\
\hline Table 1: (Reference $^{8}$ ) \\
\hline
\end{tabular}

With the exception of a few patients in whom this condition is inherited ${ }^{9}$ the etiology is as yet undetermined. Scoliosis is the most frequent anomaly found in association with this syndrome ${ }^{8}$. Of these patients, $60 \%$ have a significant degree of scoliosis ( $>15$ degrees by the Cobb method) ${ }^{8}$

Sprengel's deformity occurs in $15 \%$ to $35 \%$ of cases unilaterally or bilaterally ${ }^{10}$.At the 3rd week of gestation, the scapula develops from mesodermal tissue high in the neck at the level of fourth cervical vertebra. It descends into the thoracic position by the 8th week, or approximately at the same time that the Klippel-Feil lesion is thought to occur ${ }^{7}$. It is logical to expect a significant relationship between these two anomalies.

Our case presented with the classical triad of restricted neck movements, low hair line and short neck. Radiography confirmed the diagnosis which showed fusion of fifth and sixth cervical vertebra. It was also associated with scoliosis and Sprengel's deformity which is seen only in $30 \%$ of the cases of Klippel-Feil syndrome.

CONCLUSION: A patient with Klippel-Feil syndrome with minimal involvement can be expected to lead a normal active life with no or only minor restrictions or symptoms. Many patients with severe involvement can have the same good prognosis if early and appropriate treatment is instituted when needed. Awareness about the presence of this syndrome resulting in its early diagnosis, including that of the associated conditions, has important implications in reducing the morbidity of the patient by timely intervention.

\section{REFERENCES:}

1. Andrews, James, William; Berger, Timothy; Elston, Dirk (2005). Andrews' Diseases of the Skin: Clinical Dermatology. (10th ed.). Saunders. ISBN 0-7216-2921-0.

2. Angeli, E., Wagner, J., Lawrick, E., Moore, K., Anderson, M., Soderland, L., \& Brizee, A. (2010, May5). General format title. Retrieved From http://owl.english.purdue.edu/owl/resource/560/01/

3. Klipper Feil Syndrome [Internet] [Reviewed: December, 2011] Available from: ghr.nlm.nih.gov/condition/klippel-feil-syndrome 


\section{CASE REPORT}

4. Tracy MR, Dormans JP, Kusumi K. Klippel-Feil syndrome: clinical features and current understanding of etiology. Clin Orthop Relat Res 2004:183.

5. Cho TJ, Choi IH, Chung CY, Hwang JK. The Sprengel deformity morphometric analysis using 3DCT and its clinical relevance. J Bone Joint Surg Br. 2000; 82: 711-8. [PubMed].

6. Canale ST, Beaty JH. Campbell's Operative Orthopaedics, $12^{\text {th }}$ edition, Philadelphia, ELSEVIER MOSBY, 2013

7. Gray SW, Romaine CB, Skandalakis JF: Congenital fusion of the cervical vertebrae. Surg Gynecol Obstet 118:373, 1964.

8. Hensinger RN, Lang JR, MacEwen GD: The Klippel-Feil syndrome:A constellation of related anomalies. J Bone Joint SurgAm 56: 1246, 1974.

9. Gunderson $\mathrm{CH}$, Greenspan RH, Glaser GH, et al: Klippel-Feil syndrome: Genetic and clinical reevaluation of cervical fusion.Medicine 46:491-511, 1967. 171.

10. McElfresh E, Winter R: Klippel-Feil syndrome. Minn Med 56: 353, 1973.

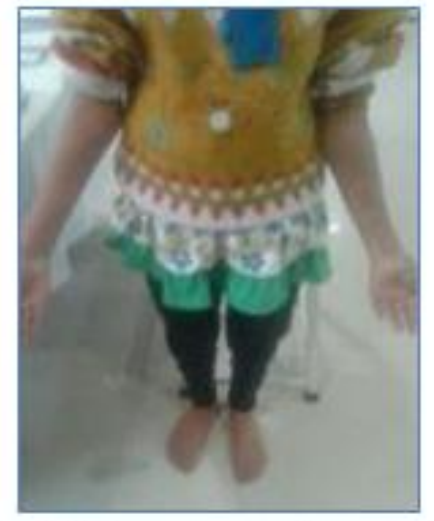

Fig. 1: Large carrying angle

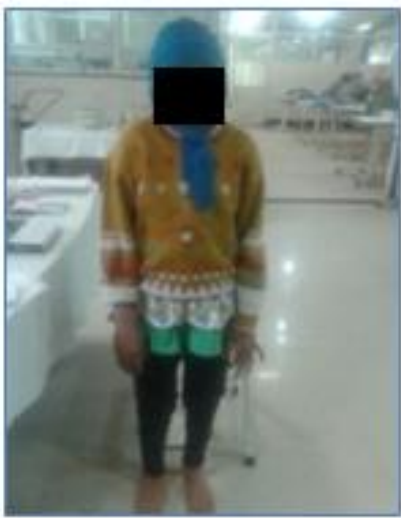

Fig. 2: Elevation of right shoulder

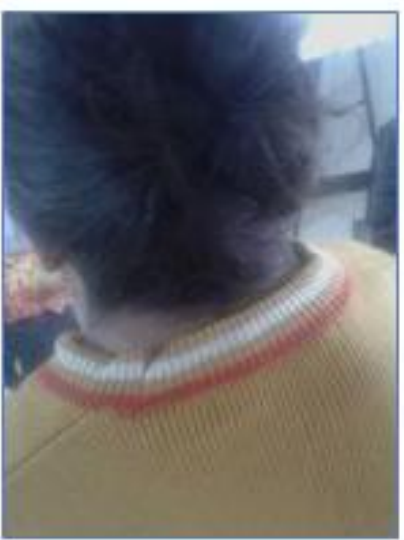

Fig. 3: Low hair line

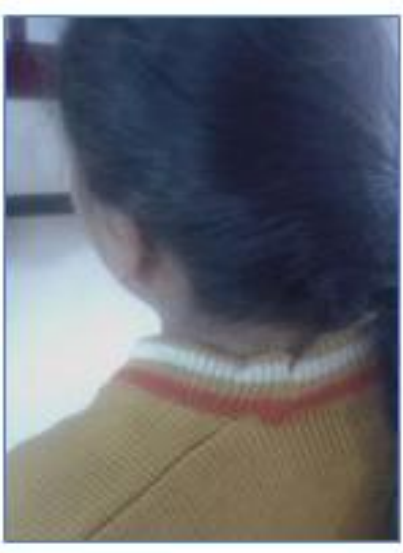

Fig. 4: Low hair line

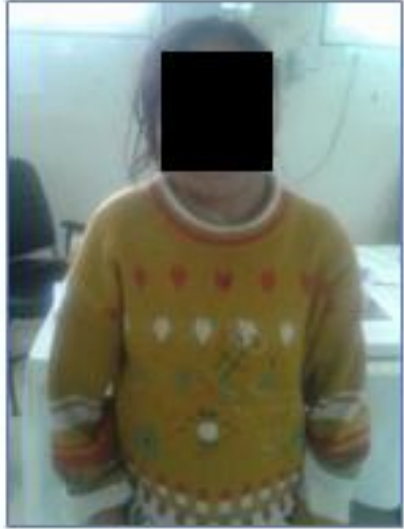

Fig. 5: Webbed neck 


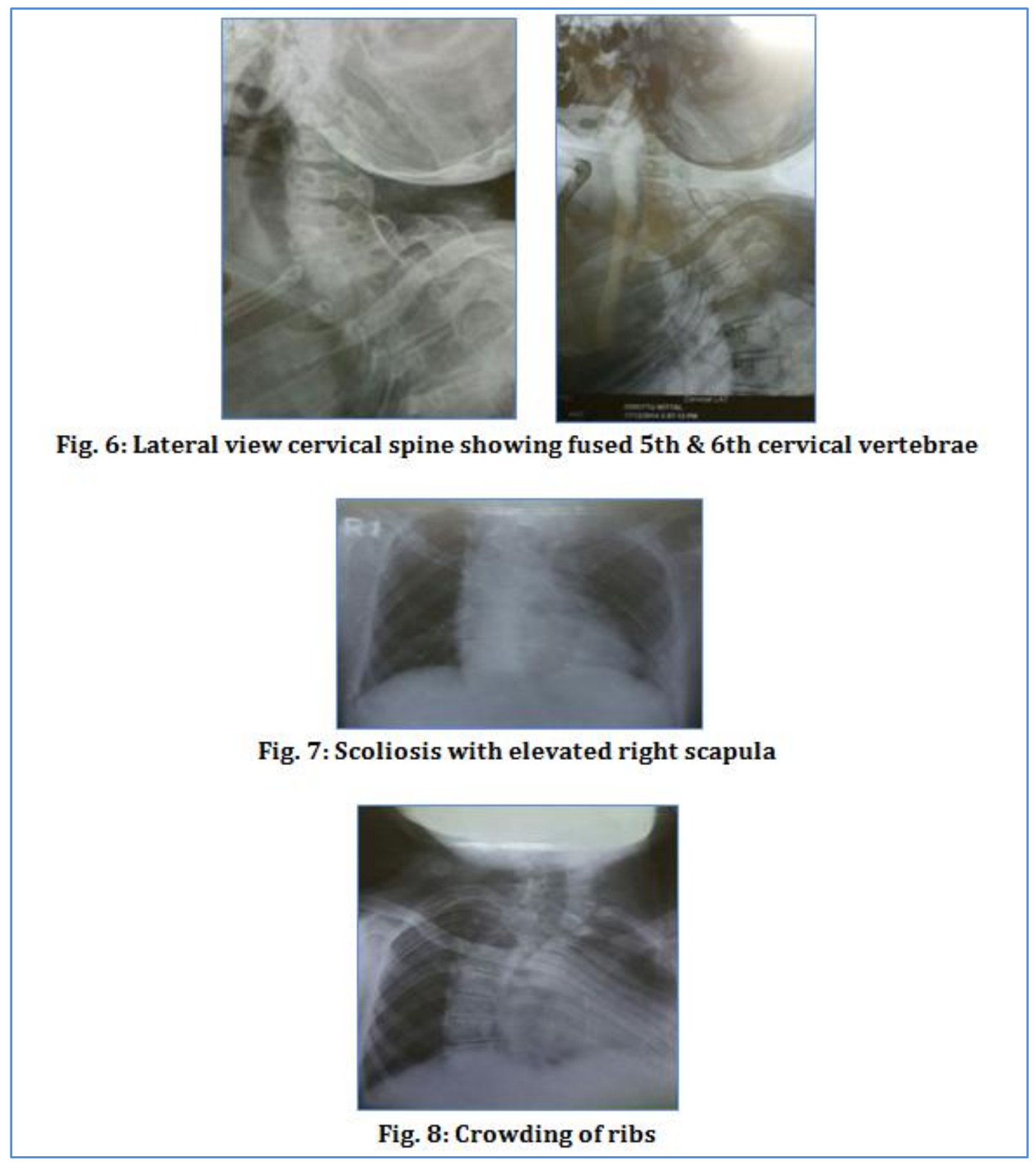




\section{AUTHORS:}

1. Ritu Mital

2. Priyanka Gupta

3. Ajeet Kumar Yadav

\section{PARTICULARS OF CONTRIBUTORS:}

1. Assistant Professor, Department of Paediatrics, LLRM Medical College, Meerut.

2. $2^{\text {nd }}$ Year Junior Resident, Department of Paediatrics, LLRM Medical College, Meerut.

3. $3^{\text {rd }}$ Year Junior Resident, Department of Paediatrics, LLRM Medical College, Meerut.

\section{FINANCIAL OR OTHER} COMPETING INTERESTS: None

\section{NAME ADDRESS EMAIL ID OF THE CORRESPONDING AUTHOR:}

Dr. Ritu Mital,

B-13, Damodar Colony,

Garh Road, Meerut-250004, U. P.

E-mail: mitalritu15@gmail.com

Date of Submission: 11/02/2015.

Date of Peer Review: 12/02/2015.

Date of Acceptance: 13/02/2015.

Date of Publishing: 23/02/2015. 